https://doi.org/10.18485/iipe_conv_conf.2021.ch6

\title{
THE MIDDLE EAST WEAPONS OF MASS DESTRUCTION FREE ZONE: RATIONALE, ATTITUDES AND WAY AHEAD
}

\author{
Marina T. Kostić1 \\ Andrej Stefanović ${ }^{2}$
}

\begin{abstract}
The 2021 events, such as the Tenth Review Conference (RevCon) of the Nuclear Non-Proliferation Treaty (NPT), the renewed IsraeliPalestinian conflict, the confirmed use of chemical weapons in the conflicts in the region, and the frequent proposals for the new Biden administration to return to the JCPOA, raised the issue of the Middle East Weapons of Mass Destruction Free Zone (MEWMDFZ) establishment high on the contemporary international agenda once again. The aim of this paper is to assess the prospects of the MEWMDFZ through the historical analysis of similar models, exploration of the rationale behind the MENWFZ/WMDFZ proposal since 1974 and its development through the subsequent decades, attitudes of key stakeholders, and the possible way ahead. The authors employ historical analysis to present the evolution of the proposal on the MEWMDFZ, content analysis of the documents adopted on this issue, and a comparative method to present the key stakeholders' points of contention and draw conclusions from similar models such as NWFZs. The authors conclude that the establishment of the MEWMDs will remain a "moving target," but one that is necessary in order to maintain the momentum of the peace process, the credibility of
\end{abstract}

\footnotetext{
${ }^{1}$ Ph.D, Institute of International Politics and Economics, Belgrade. marina@diplomacy.bg.ac.rs

The paper presents the findings of a study developed as part of the research project entitled "Serbia and Challenges in International Relations in 2021", financed by the Ministry of Education, Science, and Technological Development of the Republic of Serbia, and conducted by the Institute of International Politics and Economics, Belgrade.

${ }^{2}$ Ph.D candidate, Faculty of Political Sciences, University of Belgrade.
} 
the main stakeholders' non-proliferation policy for the Middle East, and to avoid nuclear risks for the sake of the instrumental tactical interests of regional states.

Keywords: the Middle East WMDFZ, weapons of mass destruction, nonproliferation, disarmament, the NPT, stability.

\section{INTRODUCTION}

The purpose of this paper is to assess the prospects of the establishment of a Middle East Zone free of Weapons of Mass Destruction (MEWMDFZ) as the only region for which such a proposal exists as a distinct and holistic concept. ${ }^{3}$ The 2021 events, such as the Tenth Review Conference (RevCon) of the Nuclear Non-Proliferation Treaty (NPT), the renewed Israeli-Palestinian conflict, the confirmed use of chemical weapons in the region, and the frequent proposals for the new Biden administration to return to the JCPOA, raised the issue of the MEWMDFZ establishment high on the contemporary international agenda once again.

However, having in mind the lack of empirical models and data regarding the WMDFZ, it is impossible to assess the prospects of creating this Zone through historical or case study analysis. But, this possibility exists regarding a similar model, which was also the original proposal for the Middle East until the 1990s, in the form of the Nuclear Weapons Free Zone (NWFZ). At first sight, the addition of the other WMD seems like it does not complicate the effort that much, since there are global bans and universal instruments that prohibit chemical and biological weapons on an equal footing. Still, having in mind that not all states of the Middle East region are part of this global ban and that, in some cases, chemical and biological weapons can be seen as an equaliser to nuclear weapons possession, this addition to the original proposal does complicate the effort, but seems like an inevitable one. Egypt, for example, which was also the state that proposed the establishment of the MEWMDFZ, made its participation in the Chemical Weapons Convention (CWC) and the

\footnotetext{
${ }^{3}$ The proposal for the creation of a de-facto zone free of WMD existed in 1991 in Latin America, following the Cartagena Declaration (NWFZ would be complemented by the ban on chemical and biological weapons).
} 
Biological and Toxin Weapons Convention (BTWC) conditional upon Israel's entry into the NPT. Egypt has also not ratified the Treaty of Pelindaba, which established the African NWFZ. In addition to not being a party to the NPT, Israel has also not joined the BTWC. Syria, as well, did not ratify the BTWC. The case of the WMDFZ is also prompted by the recent use of chemical weapons in the Syrian conflict in the region. ${ }^{4}$

Through historical and content analysis of the existing NWFZs and taking into account the specific additional international measures and treaties regarding the other WMD (biological, chemical, and radiological) in the first part of the paper, we will try to draw some conclusions of merit for the establishment of the MEWMDFZ. In the second part of the paper, we will deal with the characteristics of the Middle East NWFZ/WMDFZ proposal, including through analysis of the origins of the concept, its transformation, and attitudes of the parties involved by means of content analysis of the proposals, statements, and opinions of main stakeholders and final documents of multilateral forums. The third part of the paper is concerned with the assessment of the main variables identified in the first part of the paper as pertinent to the creation of the NWFZs and the identification of the way ahead regarding the proposal for the MEWMDFZ. We concluded that many of these variables or conditions are not met in the case of the Middle East, but for the reasons of the peace process, external actors' interests in maintaining the credibility of non-proliferation policy and avoiding nuclear risks, and instrumental tactical national interests of the states in the region, the proposal for the establishment of the MEWMDFZ will remain a valid and desirable option.

\section{THE HISTORY AND POLITICS OF THE NUCLEAR WEAPONS FREE ZONES AND THE CONCEPT OF THE WMD FREE ZONE}

Nuclear Weapon Free Zones (NWFZs) are usually put in the context of the disarmament agenda, even though some authors see them only as part

\footnotetext{
4 "OPCW Confirms Chemical Weapons Use in Syria," July/August 2021, Arms Control Today, https://www.armscontrol.org/act/2021-07/news-briefs/opcw-confirms-chemical-weaponsuse-syria, (accessed August 12, 2021).
} 
of non-proliferation and arms control efforts, not necessarily leading to nuclear disarmament on a global scale..$^{5}$ According to some opinions, proposals for zones free of nuclear weapons were promoted as a reaction to the obvious failure of early Cold War ambitions for general and complete disarmament, such as the "Open Skies" plan for complete disarmament presented by President Eisenhower at the 1955 Geneva Summit, or the 1956 USSR proposal for prohibiting production and the use of nuclear weapons, as well as their deployment in foreign states. ${ }^{6}$ Other authors see them in a more instrumental way - as a tool "for attaining tactical policy goals which often had little to do with the wider objectives of nonproliferation, world peace, and national economic development". ${ }^{7}$ Also, they are seen as an instrument for developing states to stay out or avoid being victims of the superpowers' nuclear arms race. ${ }^{8}$ Müller, for example, writes that "the central concern which motivated the emergence of the NWFZ concept and its implementation was the prevention of nuclear interference from outside the region". ${ }^{9}$ In this regard, this author maintains that the treaties establishing the NWFZs go beyond the NPT and that the prohibition on the stationing and deployment of nuclear weapons by outside forces is their "most meaningful contribution". ${ }^{10}$ This is also why it is important that Nuclear Weapon States (NWS) recognize the status of the NFWZs through acceptance of the protocol(s) attached to the treaties establishing the zone. Certainly, through their inclusion in the Treaty on the

\footnotetext{
${ }^{5}$ Müller mentions that the NWFZ were thus far non-proliferation instruments. Harald Müller et al., "From Nuclear Weapons to WMD: The Development and Added Value of the WMDFree Zone Concept", Non-Proliferation Papers, No. 31, September 2013, EU NonProliferation Consortium, https://www.sipri.org/sites/default/files/EUNPC_no-31.pdf, (accessed July 30, 2021), 2.

${ }^{6}$ James R. Ozinga, "An Analysis of the Rapacki Plan to Denuclearize Central Europe", Master's Theses, Graduate College, Western Michigan University, 1964, 16-17.

${ }^{7}$ Athanassios G. Platias and R. J. Rydell, "International Security Regimes: the Case of a Balkan Nuclear-Free Zone", in: South-Eastern Europe after Tito, a Powder-Keg for the 1980s, ed. David Carlton and Carlo Schaerf (London: Macmillan Press, 1983), 112.

${ }^{8}$ Radovan Vukadinović, "Prospects for Mediterranean Security: a Yugoslav View," in: SouthEastern Europe after Tito, a Powder-Keg for the 1980s, ed. David Carlton and Carlo Schaerf (London: Macmillan Press, 1983), 158.

${ }^{9}$ Müller et al., "From Nuclear Weapons to WMD", 3.

${ }^{10} \mathrm{lbid}$.
} 
Non-Proliferation of Nuclear Weapons (NPT), the NWFZs have become part of the universal nuclear non-proliferation and disarmament regime and some states, such as Egypt, see them as "instrumental in enabling the NonProliferation Treaty to achieve its objectives and aims". ${ }^{11}$ Their importance also lies in the fact that over 100 countries in the world participate in the NWFZs, which cover over $50 \%$ of the world's surface, with the figures being even more outstanding for the southern hemisphere, as $99 \%$ of the surface is covered by the NWFZs. ${ }^{12}$

Historically speaking, the NWFZ proposals were developed in the 1950s. The already mentioned 1956 USSR proposal was further elaborated in another Soviet project submitted to the 1956 meetings of the UN Disarmament Commission, which suggested creating in Central Europe (extending to both Germanies and countries "adjacent to them") a zone free from the stationing of nuclear forces. ${ }^{13}$ Mirroring this proposal, a Polish initiative known as the Rapacki Plan, named after the former Polish Minister of Foreign Affairs, was proposed in 1957, which promoted the idea of a zone encompassing West and East Germany, as well as Poland and Czechoslovakia, in which the production, stockpiling, import, and deployment of any type of nuclear weapon would be prohibited, while nuclear weapon states would be required to commit not to maintain nuclear forces in the zone, nor to deploy nuclear weapons. ${ }^{14}$ It is widely assumed that many NWFZs were proposed in response to "trigger events", but the Rapacki Plan did indeed follow a NATO decision to install American intermediate-range ballistic missiles (IRBMs) in West Germany. ${ }^{15}$ On the

11 "Egypt: Ratification of Treaty on the Non-Proliferation of Nuclear Weapons (NPT)," https://treaties.unoda.org/a/npt/egypt/RAT/london, (accessed August 19, 2021).

${ }^{12}$ Cecilie Hellestveit and Daniel Mekonnen, "Nuclear weapon-free zones: the political context", in: Nuclear Weapons under International Law, ed. Gyo Nyustuen, Stuart CaseyMaslen and Annie Golden Bersagel, (Camrbidge: Cambridge University Press, 2014), 347.

13 "Official Records, Supplement for January to December 1956," Disarmament Commission, 1956, https://s3.amazonaws.com/unoda-web/documents/library/Supplement\%20for\% 201956.pdf, (accessed July 3, 2021), 11.

14 "The Rapacki Plan", 14 February 1958, Centre Virtuel de la Connaissance sur l'Europe, https://www.cvce.eu/en/obj/the_rapacki_plan_warsaw_14_february_1958-en-c7c21f7783c4-4ffc-8cca-30255b300cb2.html, (accessed July 3, 2021).

${ }^{15}$ Platias and Rydell, "International Security Regimes," 111-112. 
other hand, it was seen as a pure Polish initiative or "manoeuvre" aimed at disengagement from any possible nuclear confrontation, avoidance of the stationing of any nuclear weapons on its soil, and gaining security assurances from the NWS that they would not use nuclear weapons against countries covered by the proposal (fear of invasion such as the one that occurred in Hungary was part of the motivation). ${ }^{16}$ Thus, in the political climate of the late 1950s, the Rapacki Plan had little, if any, chance of being adopted, as the Western states saw it as a Soviet ploy to create supplementary advantage for the Eastern Bloc, which already had the upper hand in conventional forces on the continent. ${ }^{17}$ The Rapacki Plan was actually a convenient way for the USSR to prevent Germany from acquiring nuclear weapons, a long-standing aim of the USSR during the Cold War, as well as Russia today. Despite being unsuccessful at first, this innovative concept proved to be useful in elaborating the principal framework of a NWFZ and served as a model for other countries, which took up many of the principles found in the Rapacki Plan (such as the total absence of nuclear weapons, the existence of a verification and control system, and the obligation on the part of the NWS to provide guarantees that they would not use nuclear weapons against the zone) in the construction of NWFZs in their respective regions. ${ }^{18}$ At the same time, the differences in geography, politics, culture, strategy, and economics meant that it was impossible to attain a truly uniform model of a NWFZ, and in practice, these regimes differed in the scope of states parties' obligations, responsibilities of states outside of the zone, geographical delimitation of

\footnotetext{
${ }^{16}$ Valeria Puga Alvarez, "Functional peace? The "first wave" of Nuclear-Weapon-Free Zone sproposals in the Cold War", Grotius, https://www.academia.edu/43482987/Functional _peace_The_first_wave_of_nuclear_weapon_free_zones_proposals_in_the_Cold_War?e mail_work_card=thumbnail, 4 (accessed August 20, 2021).

${ }^{17}$ Zoltan Marusza, "Denuclearization in Central Europe? The Rapacki Plan during the Cold War", Cold War History Research Center, Budapest, 2010, 12; Michael Hamel-Green, "Peeling the orange: regional paths to a nuclear-weapon-free world," in: Nuclear-weaponfree zones, ed. Kerstin Vignard and Ross McRae, (Geneva: United Nations for Disarmament Research, 2011), 4.

${ }^{18}$ Hellestveit and Mekonnen, Nuclear weapon-free zones: the political context, 348; HamelGreen, Peeling the orange: regional paths to a nuclear-weapon-free world, 4; Jozef Goldblat, Arms Control: The New Guide to Negotiations and Agreements, (London, Thousand Oaks and New Delhi: PRIO, SIPRI and SAGE Publications, 2002), 196.
} 
the zone, verification arrangements, conditions for entry into force, as well as the right to terminate and leave. ${ }^{19}$

Apart from the Rapacki Plan and the proposal for the creation of the NWFZ in Central Europe, there were proposals to create Balkan and Scandinavian NWFZs. In fact, between the 1950s and 1960s, there were at least several "proposals" for establishing a NWFZ in the Balkans (or including the Balkans). ${ }^{20}$ The Soviet Union supported the second Romanian proposal (from 1959, while the first one was made in 1957) on the Balkan Peace Zone and the creation of a Balkan NWFZ, including the Adriatic, after the installation of Jupiter IRBMs in Italy and Turkey, but the proposal was unsuccessful since the US found it incompatible with its and its allies' security interests. ${ }^{21}$ Furthermore, in 1963, there was a Soviet proposal for the establishment of a Mediterranean NWFZ, which was triggered by NATO plans to deploy Polaris submarines in the Mediterranean. ${ }^{22}$ One of the proposals for a NWFZ covering both the Balkans and the Mediterranean was put forward by Bulgaria and Yugoslavia in 1968, while the latest initiative was advanced in 1981 by Greece (after the victory of PASOK that year) and Romania, but none succeeded, since the West saw them as Soviet tools for rebalancing power in Europe. ${ }^{23}$ Vukadinović, for example, thought that the Middle East NWFZ could be extended to the Balkans and encompass the unique Meditearranean region which would be covered by the NWFZ, as proposed by the Non-Alignment Movement. ${ }^{24}$

As was observed by one author, the emergence of the NWFZs bears a resemblance to peeling an orange - first the zone in the Antarctic was created in 1959, followed by the Latin American one in 1967, with the process continuing during the 1980s, 1990s, and 2000s in Africa, the South Pacific, South-East Asia, and Central Asia. ${ }^{25}$ Despite their opposition to the Rapacki Plan, Western states were later on in the forefront of promoting

\footnotetext{
${ }^{19}$ Goldblat, Arms Control, 198.

20 Platias and Rydell, "International Security Regimes," 120.

${ }^{21}$ Alvarez, "Functional peace?," 5.

22 Platias and Rydell, "International Security Regimes," 112.

${ }^{23}$ Alvarez, "Functional peace?," 5.

${ }^{24}$ Vukadinović, "Prospects for Mediterranean Security," 159.

${ }^{25} \mathrm{Hamel-Green,} \mathrm{Peeling} \mathrm{the} \mathrm{orange:} \mathrm{regional} \mathrm{paths} \mathrm{to} \mathrm{a} \mathrm{nuclear-weapon-free} \mathrm{world,} 3$.
} 
the creation of the first NWFZ, albeit on uninhabited land - the Antarctic. The 1959 Antarctic Treaty established a zone free of nuclear weapons (and a demilitarised zone all together), prohibiting nuclear explosions and weapon testing. ${ }^{26}$ Similar instruments were adopted in the following decades for Outer Space, the Moon, the Sea-Bed, the Ocean Floor, and the Subsoil. The efforts to establish the NWFZs in populated areas followed the Antarctic Treaty, as the Latin American countries, alarmed by the potential catastrophic consequences of the 1962 Cuban Crisis, came together and adopted the 1967 Tlatelolco Treaty, which established a NWFZ in Latin America and the Caribbean, with the most salient features inspired by the proposals of the Rapacki Plan. ${ }^{27}$ Adopted at the height of the Cold War, the Tlatelolco Treaty is often cited as a "success story" of what can be achieved despite great differences and difficulties. ${ }^{28}$

Prior to reaching the Tlatelolco Treaty, the growing international attraction of the NWFZ concept continued unabated in the United Nations. In 1965, the United Nations General Assembly (UNGA) adopted a resolution which affirmed the right of groups of states to agree on a treaty-based absence of nuclear weapons from their territories. ${ }^{29}$ This principle was subsequently reaffirmed by the UNGA in a 1975 resolution, which also provided a definition of the NWFZs through enumerating a number of constitutive elements. This can be summed up as follows: a NWFZ entails the existence of a treaty envisaging the total absence of nuclear weapons in a geographically delimitated zone, accompanied by a system of verification and control of compliance, with nuclear weapon states being called upon to respect, in legally binding terms, these regimes, and in so doing not to violate them, including through the use or threat to use nuclear weapons against them. ${ }^{30}$ The Tlatelolco Treaty, together with UNGA

\footnotetext{
${ }^{26}$ Ibid., 5.

${ }^{27}$ Ibid., 5.

${ }^{28}$ Hellestveit and Mekonnen, Nuclear weapon-free zones: the political context, 354.

29 "Non-proliferation of nuclear weapons," UN General Assembly, Resolution 2028, A/RES/ 2028, November 19, 1965, https://www.securitycouncilreport.org/atf/cf/\%7B65 BFCF9B6D27-4E9C-8CD3-CF6E4FF96FF9\%7D/Disarm\%20ARES2028.pdf, (accessed July 5, 2021).

30 "Comprehensive Study of the question of nuclear-weapon-free zones in all its aspects," UN General Assembly, Resolution 3472, December 11, 1975, https://digitallibrary.un. org/record/640307?!n=en, (accessed July 5, 2021).
} 
and NPT norms, served as a guide for the South Pacific states, which, due to raised concerns because of French nuclear tests, established a NWFZ through the adoption of the 1985 Rarotonga Treaty. It not only banned nuclear weapons and all forms of nuclear activity, but also prohibited nuclear weapons testing in the entire zone, as well as the dumping of nuclear waste. ${ }^{31}$

Despite calls for NWFZs in other parts of the world in the 1960s and 1970s, due to the difficult and unfavourable international situation, these initiatives did not come to fruition until the Cold War's end. In South East Asia, for example, the Zone of Peace, Freedom, and Neutrality, a precursor of the future zone, was established in 1971. However, a full-fledged NWFZ was not feasible due to Thailand's and the Philippines' foreign policy alignment with the US. After the end of the Cold War, countries in Southeast Asia adopted the 1995 Bangkok Treaty, the provisions of which went a step further compared to the Tlatelolco and the Rarotonga Treaties, as it extended the obligations of nuclear weapons absence to the exclusive economic zones of state parties, a crucial reason why the nuclear weapon states were reluctant to give this zone the requested negative assurances. ${ }^{32}$ With regard to the African continent, interest in a NWFZ also emerged in the 1960s, triggered by French nuclear testing in the Sahara and ignited by the development of the South African nuclear program. With the Cold War drawing to an end, in 1990, the UNGA adopted a resolution calling for the implementation of the 1964 Organization of African Unity Declaration, which committed African states to denuclearizing the continent. Subsequent negotiations resulted in the 1996 Pelindaba Treaty, which included provisions relating to the dismantling of existing nuclear facilities. ${ }^{33}$ The latest NWFZ was created in Central Asia through the adoption of the 2006 Semipalatinsk Treaty, where the aspiration for a zone was triggered by regular nuclear testing, as well as other nuclear-related activities (processing of nuclear fuel, stockpiling of nuclear weapons and fission material) conducted by the USSR. Because of this, the Treaty contains

\footnotetext{
${ }^{31}$ Hamel-Green, Peeling the orange: regional paths to a nuclear-weapon-free world, 6.

${ }^{32}$ Hellestveit and Mekonnen, Nuclear weapon-free zones: the political context, 356-357; Hamel-Green, Peeling the orange: regional paths to a nuclear-weapon-free world, 7.

${ }^{33}$ Hamel-Green, Peeling the orange: regional paths to a nuclear-weapon-free world, 7-8.
} 
provisions for assistance in environmental rehabilitation of contaminated areas and bans nuclear weapons research. ${ }^{34}$

The latest contribution to the development of the NWFZ concept took place in 1999, when the UN Disarmament Commission, in its report, recommended a set of principles and guidelines for the establishment of a nuclear-weapon-free zone such as that they should be established on the initiative of the state(s) of the region and include regional states who, by their free will, choose to create such a zone, as well as that the NWS should be consulted during this process in order to facilitate their acceptance of the security assurances (protocol(s)) and that this zone will in no way influence the peaceful use of nuclear energy. ${ }^{35}$

However, not all NWS ratified the NWFZ protocol(s). Through these protocol(s), NWSs make legally binding commitments to the zone's status and to refrain from using or threatening to use nuclear weapons against treaty parties. Regarding the Latin America and the Caribbean NWFZ (Tlatelolco Treaty), all five NWS ratified the First Protocol, with China remaining the only NWS that has not ratified the Second Protocol. Concerning the South Pacific NWFZ (Rarotonga Treaty), France and the United Kingdom have ratified all three protocols; China and Russia have ratified only the II and the III, while the United States has not ratified a single Protocol, although it signed all three in 1996. No NWS has signed the Protocol to the South East Asia NWFZ (Bangkok Treaty). Four NWS have ratified Protocols I and II of the African NWFZ (Pelindaba Treaty), with the US being the only exception, as it only signed them in 1996. On the other hand, Protocol III was ratified only by France. In relation to the Central Asia NWFZ, the Protocol has been ratified by four NWS, with the US again being the only NWS to deviate, even though it signed the Protocol in 2014. ${ }^{36}$

When it comes to the relationship with the NPT and having in mind the obstacles to the Middle East NWFZ, it is important to stress that, according

\footnotetext{
34 Ibid., 8; Hellestveit and Mekonnen, Nuclear weapon-free zones: the political context, 359.

35 "Nuclear-Weapon-Free Zones", UNODA, https://www.un.org/disarmament/wmd/nuclear/ nwfz/, (accessed August 15, 2021).

${ }^{36}$ Status and details of the Protocols can be found on: "Protocols to the Nuclear-WeaponFree-Zone Treaties", https://www.un.org/nwfz/content/protocols-nuclear-weapon-freezone-treaties, (accessed August 15, 2021).
} 
to the research conducted by the authors of this paper, only in the case of the first NWFZ (1967) - in Latin America - there were several states that ratified or acceded to the NPT only after they joined the Treaty of Tlatelolco (and when both were open for signature, i.e. after 1968), with some of them, like Brazil, being members of the Zone for as much as thirty years before ratifying the NPT, while having a nuclear weapons programme during the 1970s and 1980s, but never developing a nuclear weapon. This means that they were not part of the NPT at the moment they became part of the NWFZ. But, in any other case involving the NWFZ, all parties to the NWFZ had previously ratified or acceded to the NPT.

Overall, having in mind all the mentioned cases of successful and unsuccessful proposals for the NWFZs, several findings can be relevant for assessing the prospect of the Middle East NWFZ/WMDFZ: (1) the NWFZs were established by the member states who believed that it increased rather than decreased their security and contributed to the overall stabilization of the region covered by the NWFZ; (2) the NWFZs never included countries where some of them had capabilities to become hegemonies or were practicing hegemony; (3) the NWFZs never included countries that were experiencing existential threats; (4) the NWFZs tended to protect member countries from external hegemonies and arms races and were created in the areas close to the NWS, but were at the same time not essential for the strategic stability (deterrence) among superpowers; ${ }^{37}$ (5) the NWFZs never included countries that possessed nuclear capabilities, and countries that did have such capacities had to relinquish them in order to enter the Zone. Nonetheless, the decision to destroy the nuclear weapons programme was prompted by other considerations, and was only thereafter followed by the decision to join the zone (as in the case of South Africa).

Apart from nuclear weapons, there were also proposals to create Chemical Weapon Free Zones (CWFZs), which would include both regional and sub-regional initiatives, and, as in the case of nuclear weapons, they were mostly focused on Central Europe (proposed by the Warsaw Treaty members and two German states), the Balkans (proposed by Bulgaria and

\footnotetext{
${ }^{37}$ More on strategic stability see: Marina T. Kostić, "Controversial issues regarding the extension of the "New START" Treaty: Can the USA and Russia preserve existing strategic arms control?", Serbian Political Thought 70, No. 4, (2020): 124-128.
} 
Romania), Scandinavia, the Mediterranean, and Latin America. ${ }^{38}$ But, after the conclusion of the global ban on chemical weapons (CWC) in 1993, all regional CW-ban initiatives were abandoned and "all of these plans and proposals evaporated". ${ }^{39}$ Since the global ban on biological weapons (BTWC) was introduced early on, the regional approach to this matter did not develop. ${ }^{40}$ Following this line of thinking, one could conclude that with the adoption of a global ban on nuclear weapons (such as the one proposed by the Treaty on the Prohibition of Nuclear Weapons), the concept of the NWFZs might also be abandoned or serve as an easier accession to this ban treaty.

After presenting the history of the idea of the Middle East NWFZ/WMDFZ, we will assess the prospect of establishing such a zone by examining the above-mentioned conditions, i.e., variables. Despite the fact that the conditions for establishing such a zone have not been met, negotiations on the zone are likely to continue in the larger interest of nonproliferation of surrounding regional and global powers.

\section{THE RATIONALE FOR PURSUING A MIDDLE EAST ZONE FREE OF NUCLEAR WEAPONS (AND OTHER WEAPONS OF MASS DESTRUCTION)}

\section{Origins of the Initiative and the main obstacles for the creation of the NWFZ}

At approximately the same time when the Rapacki Plan was presented to the international community, the Soviet Union pressed hard for the Middle East to become a "zone of peace free of nuclear weapons and missiles, and also of good neighbourly relations and cooperation". ${ }^{41}$ In this endeavor, the Soviets were motivated by the awareness that plans for

\footnotetext{
${ }^{38}$ Müller et al., "From Nuclear Weapons to WMD", 7.

39 Ibid.

${ }^{40}$ Ibid., 9.

41 "Soviet Initiative calls for a nuclear-weapon-free zone in the Middle East", United Nations Institute for Disarmament Research, https://unidir.org/timeline/1950s/soviet-initiativecalls-nuclear-weapon-free-zone-middle-east, (accessed July 15, 2021).
} 
universal disarmament were not going to materialize, as well as a fear that the US might share its nuclear weapons with allies in the Middle East. The USSR pursued this agenda and engaged Iran a year later, mostly due to concerns raised by the 1959 US-Iran security agreement. In a note to its authorities, the USSR urged the establishment of a nuclear weapons free zone in the Middle East. ${ }^{42}$

The first wave of initiatives for regional nuclear weapon-free zones, including one confined to the Middle Eastern space, faded in the mid-1960s as a result of the emergence of a global non-proliferation regime (i.e., the adoption of the NPT), which aimed to limit the size of the global nuclear states club. ${ }^{43}$ Nonetheless, it did not take long for the cracks, gaps, and weaknesses in the NPT regime to become evident, especially as many key countries (such as China, India, Pakistan, and Israel) decided to remain outside of the Treaty. With this in mind, interest in a regional nonproliferation and disarmament approach was restored during the 1970s in various parts of the world. This renewed interest was also manifested in the UNGA, as one-half of the disarmament resolutions became directly linked to the issue of the NWFZs. ${ }^{44}$ During the UNGA's 25th session in 1970, Iran announced for the first time its willingness to declare the Middle East a nuclear-free zone, if other countries in the region agreed to such an exploit. ${ }^{45}$ This commitment was reiterated a year later, with Iran calling upon neighbouring countries to reach an agreement on the Middle East nuclear free zone. ${ }^{46}$ The proposal was strengthened after the 1973 Yom Kippur war, and in 1974, the initiative was endorsed by the Shah of Iran, Reza Pahlavi, in a letter addressed to the UN Secretary-General. In it, the Shah confessed

42 Unto Vesa, "The Revival of Proposals for Nuclear-Free Zones", Instant Research on Peace and Violence 5, no. 1, (1975): 43; John C. Campbell, "The Soviet Union and the United States in the Middle East," The Annals of the American Academy of Political and Social Science 401, no. 1 (1972): 131.

${ }^{43}$ Vesa, "The Revival of Proposals for Nuclear-Free Zones," 44.

${ }^{44}$ Ibid.

45 "Twenty-fifth session Official Records," UN General Assembly,1857th plenary meeting, October 1, 1970, https://digitallibrary.un.org/record/740456? In=en, (accessed July 15, 2021), 5.

46 "Twenty-sixth session Official Records," UN General Assembly, 1941st plenary meeting, September 27, 1971, digitallibrary.un.org/record/734914?In=en, (accessed July 15, 2021). 
his understanding of the obstacles that stand in the way of realising such an initiative, but he also underlined that Iran had received support from many governments, both inside and outside the region. ${ }^{47}$ In preparing for the commencement of the 29th UNGA session, scheduled for September 1974, the Iranian delegation requested, for the first time, to include an item on the UNGA agenda concerning the establishment of a nuclear-free zone in the Middle East. ${ }^{48}$ Eventually, Egypt joined as a co-sponsor of the request, and the two countries quickly reached an understanding to rename the initiative "the establishment of a nuclear-weapons-free zone in the region of the Middle East". On the basis of a draft submitted by the two delegations, the UNGA adopted a resolution on the establishment of the NWFZ in the Middle East, with a total of 125 UN member states supporting it, only two countries abstaining (Israel and Burma), and none against. ${ }^{49}$

In line with a request made by UN member states in this resolution, the UN Secretary General published a Report on the views of interested states regarding its implementation. This document was important as it contained, for the first time, the delineation of the proposed zone. Apart from expressing their readiness to refrain from producing, testing, and acquiring nuclear weapons, many Arab states pointed to the fact that Israel had still not joined the NPT, and they conditioned their ratification of the Treaty upon Israel's accession. Israel, for its part, in supporting the establishment of the zone as a "desirable further step towards a just and durable peace in the region", underlined that the goal can be accomplished only by a formal agreement between all states of the region, and expressed its readiness to participate at a conference convened for this purpose. In

47 "Request for the inclusion of an item in the provisional agenda of the twenty-ninth session," UN General Assembly, A/9693/Add. 3, September 17, 1974, https://unidir.org/sites/default/ files/2020-11/1974\%20Shah\%20UN\%20letter.pdf, (accessed July 15, 2021).

48 "Establishment of a nuclear-weapon-free zone in the region of the Middle East," UN General Assembly, Resolution 3263, A/RES/3263, December 9, 1974, https://www.security councilreport.org/un-documents/document/disarm-ares3263-xxix.php, (accessed July 15, 2021).

49 "Iran and Egypt co-sponsor a resolution calling for the establishment of a nuclear-weaponfree zone in the Middle East," UNIDIR, https://unidir.org/timeline/1970s/iran-and-egyptco-sponsor-resolution-calling-establishment-nuclear-weapon-free-zone, (accessed July 16, 2021). 
relation to the NPT, Israel voiced its concerns because Arab states frequently threatened to use force against it and continuously tried to exclude it from the international community. ${ }^{50}$ Egypt, in its reply to this statement, stressed that by insisting on negotiations as the only way to establish the zone, the Israelis not only rejected the initiative up front, but also effectively evaded joining the NPT. ${ }^{51}$

After 1974, the resolution on the Middle East NWFZ became a regular item on the agenda of the UNGA. The resolutions adopted throughout the second part of the 1970s resembled the original resolution significantly, with the addition of calls to regional states to place their nuclear activities under an effective system of safeguards operated by the International Atomic Energy Agency (IAEA). These resolutions were adopted by a resounding majority, with no votes against and only Israel abstaining, something which was justified by "reservations with regard to the wording of the resolution". 52 Many elements from these resolutions were incorporated into relevant paragraphs of the Final Document from the 1978 UNGA's $10^{\text {th }}$ Special Session dedicated to Disarmament. It contained calls to establish a Middle East NWFZ, having in mind the support expressed by all concerned states and acknowledging the contribution it would make to international peace and security. It was also asserted that, pending the establishment of such a zone, the states in the region ought to proclaim their commitment to refraining from acquiring nuclear weapons on a reciprocal basis. ${ }^{53}$

The $35^{\text {th }}$ UNGA session in 1980 was a turning point as the resolution on the Middle East NWFZ was adopted for the first time without a vote. The resolution was drafted along the same lines as its precursors, with

\footnotetext{
50 "Report of the Secretary General on the establishment of a nuclear-weapon-free zone in the region of the Middle East." UN Secretary General, 1975S/11778, https://www.unidir. org/sites/default/files/2020-10/1975_SecGenReport.pdf, (accessed July 16, 2021), 11.

51 Ibid., 13.

52 "Thirty-fourth session Official Records," UN General Assembly, 70th Plenary meeting, October 16, 1979, https://digitallibrary.un.org/record/754036? In=en, (accessed July 18, 2021), 38-40.

53 "Final Document of the Tenth Special Session of the General Assembly," UN General Assembly, 1978, https://digitallibrary.un.org/record/218448?!n=en, (accessed July 18, 2021), 8 .
} 
paragraphs dedicated to the adherence to the NPT, placing nuclear activities under IAEA safeguards, and provisions on refraining from the production and acquisition of nuclear weapons pending the establishment of the zone..$^{54}$ Prior to its adoption, Israel's delegation submitted to the UNGA an alternative resolution on the same subject, which called on all states in the region, as well as all other adjacent states that are not parties to any NWFZ treaty, to convene a conference in order to negotiate a multilateral treaty for the establishment of a NWFZ in the Middle East. However, their proposal was immediately rejected by the Arab states, which prompted the Israelis to withdraw their resolution and eventually decide to vote in favour of the resolution sponsored by Egypt. A turn in Israel's stance was caused in part by accusations that it dismissed calls for a Middle East NWFZ, as alleged in the Secretary General's 1980 Comprehensive Study on Nuclear Weapons. ${ }^{55}$ Reacting to this remark, Israel's Minister of Foreign Affairs at the time explained that Israel had continuously supported the establishment of a NWFZ in the region, and that they actually viewed regional arrangements as the best mechanism to solve the issue of nuclear proliferation. However, it was once again stressed that such a zone should follow the example of the "Tlatelolco model", i.e., that it should be achieved through a multilateral convention between all states of the region negotiated at an international conference. ${ }^{56}$

Despite their draft being rejected in 1980, Israel pushed forward again the next year, during the $36^{\text {th }}$ UNGA session, by requesting all states concerned to indicate their readiness to hold a preparatory meeting to discuss the modalities of a conference for adopting a multilateral treaty that would establish a NWFZ in the Middle East. At the same time, the Arab

54 "Establishment of a nuclear-weapon-free zone in the region of the Middle East." UN General Assembly, Resolution 35/147, A/35/PV.94, December 12, 1980, https://undocs. org/en/A/RES/35/147 (accessed July 18, 2021).

55 "Comprehensive study on nuclear weapons," Report of the Secretary General, UN Secretary General, A/35/392, September 12, 1980, https://digitallibrary.un.org/record/ 15382? In=en, (accessed July 20, 2021), 143.

56 "Lettre datéee du 23 octobre 1980, adressée au Secrétaire général par le Représentant permanent d'Israel auprès de l'Organisation des Nations Unies," Nations Unies Assemblee, A/C.1/35/8, Octobre 24, 1980, https://digitallibrary.un.org/record/16331?ln=en, (accessed July 20, 2021). 
states used every opportunity to point out the dangers of Israel's nuclear capabilities, which they designated as the greatest threat to the establishment of the zone. In 1979, the United Nations General Assembly passed a resolution expressing concern that Israel's nuclear capabilities would exacerbate already volatile regional security and endanger international peace..$^{57}$ These fears were further exacerbated in June 1981 when Israel attacked an Iraqi nuclear research centre, which prompted the Security Council to adopt a resolution in 1981 that called upon Israel to urgently place its nuclear facilities under IAEA safeguards. ${ }^{58}$ These calls were repeated within the IAEA in a resolution adopted by its General Conference in September 1987, which made a direct reference to the "recent information regarding the possession of nuclear weapons by Israel". ${ }^{59}$

Apart from this, the second part of the eighties was important in further elaborating the concept of a NWFZ in the Middle East. Acting upon a request made by Egypt in 1988, the UN Secretary General conducted a study on effective and verifiable measures which would "facilitate the establishment of a NWFZ in the Middle East, taking into account the circumstances and characteristics of the Middle East" ${ }^{60}$ It also explored the geographical delimitation of the zone, as it included in the process all member states of the Arab League, plus Iran and Israel, and introduced the concepts of "core" and "peripheral countries", which implies the existence of a smaller group of states that are essential to the initiation, establishment, and operation of the zone, while the other, larger group of countries, is important for the agreement to enter into force. From the perspective of the Arab states and Iran, the problem continued to be Israel's

\footnotetext{
57 "Israeli nuclear armament," UN General Assembly, Resolution 34/89, A/RES/34/89, December 11, 1979, https://undocs.org/en/A/RES/34/89, (accessed July 20, 2021).

58 "On the Israeli military attack Iraqi nuclear facilities," UN Security Council, Resolution 487 (1981), S/RES/487, June 19, 1981, https://digitallibrary.un.org/record/22225?!n=en, (accessed July 20, 2021).

59 "IAEA resolution on the 'Israeli nuclear capabilities and threat' is adopted for the first time," UNIDIR, https://unidir.org/timeline/1980s/iaea-resolution-israeli-nuclear-capabilities-andthreat-adopted-first-time, (accessed July 20, 2021).

60 "Establishment of a nuclear-weapon-free zone in the region of the Middle East," UN General Assembly, Resolution 45/52, A/RES/45/52, December 19, 1990, https://digital library.un.org/record/104358?!n=en, (accessed July 20, 2021).
} 
nuclear capabilities and its absence from the NPT and IAEA safeguards. On the other hand, Israel's difficulty was attributed to the unwillingness of other countries in the region to accept it as a legitimate state and to sit at a negotiating table in order to agree on the zone's arrangements.

\section{A Zone Free of All Weapons of Mass Destruction}

Israel's nuclear armament was, however, not the only problem facing the Middle East. Certain countries in the region were recorded as stockpiling chemical weapons, which were even used by some of them in conflict situations (such as the decade-long Iran-Iraq War). Even though never used, there was also strong suspicion of developing biological weapons programmes in the Middle East. ${ }^{61}$ Looking to encompass all these threats, in 1990, the former Egyptian President Hosni Mubarak called for the Middle East to be rid of all WMD (i.e. nuclear, chemical, and biological) without exception, and that, consequentially, all states concerned should make commitments to this end. In order to ensure compliance, he advocated for adequate verification measures to be put in place. ${ }^{62}$ This proposal, which came to be known as the "Mubarak Initiative", effectively put the prospective Middle East zone at a qualitatively different level compared to all other NWFZs. A year later, the UNSC, in a resolution that terminated the 1991 Gulf War (UNSC Res. 687), inter alia, recalled "the need to work towards the establishment in the Middle East of a zone free of such weapons", and that Iraq's disarmament, required by this resolution, "represents steps towards the goal of establishing in the Middle East a zone free from weapons of mass destruction and all missiles for their delivery". ${ }^{63}$ At about the same time, the former US President George Bush, in an address delivered before a joint session of the US Congress on March 6 , 1991, on the occasion of the end of the Gulf War, committed the US to controlling the spread of WMD and the missiles for their delivery in the

\footnotetext{
61 "Weapons of Mass Destruction in the Middle East", Nuclear Threat Initiative, https://www. nti.org/analysis/articles/weapons-mass-destruction-middle-east/, (accessed July 27, 2021).

62 "On restoration of the sovereignty, independence and territorial integrity of Kuwait," UN Security Council Resolution 687 (1991), S/RES/687, 3 April 1991, https://digitallibrary.un. org/record/110709? In=en, (accessed July 27, 2021).

${ }^{63}$ Ibid.
} 
Middle East. ${ }^{64}$ This commitment was subsequently elaborated in a White House Middle East Arms Control Initiative, which called upon all countries concerned to accede to the relevant international instruments (the NPT, BTWC, and (WC), also envisaging a verifiable ban by regional states on the production and acquisition of weapons grade fission material. ${ }^{65}$ This initiative was afterwards discussed in the framework of the $P 5$ process (five nuclear weapon states) during 1991 and 1992, resulting in support by the P5 for the establishment of the Middle East WMDFZ, in accordance with UNSC resolution 687 on the end of the Iraq-Kuwait War (April 1991). ${ }^{66}$

In August 1991, Egypt and other Arab states requested the IAEA Director General to include a new item on the IAEA General Conference's agenda - the Application of IAEA safeguards in the Middle East. The resolution under this item ended up being adopted without a vote. It referred to the urgent need for all states in the Middle East to accept the IAEA's safeguards over all of their nuclear activities and to take measures, including confidence-building and verification, in order for the NWFZ to be established in the Middle East. ${ }^{67}$ Israel backed the consensus on this item as a result of the agreement that the resolution on Israeli nuclear capabilities and threats (adopted for the first time in 1987 and included annually in the IAEA General Conference's agenda) would not be put to a vote. Other members approved this maneuver, seeing it as a measure conducive to the peace process in the Middle East. ${ }^{68}$ The UN Secretary

\footnotetext{
64 "Address Before a Joint Session of Congress on the End of the Gulf War," University of Virginia Miller Center, March 6, 1991, https://millercenter.org/the-presidency/presidential-speeches /march-6-1991-address-joint-session-congress-end-gulf-war, (accessed July 27, 2021).

65 "The Fact Sheet: Middle East Arms Control Initiative," The White House: The Office of the Press Secretary, May 29 1991, https://www.dscu.mil/Pubs/Indexes/Vol\%2013_4/Fact\%20Sheet \%20Middle\%20East\%20Arms\%20Control\%20Initiative.pdf, (accessed August 7, 2021), 2.

66 "P5 express their support for a ME WMDFZ," UNIDIR, 1991, https://unidir.org/timeline /1990s/p5-express-their-support-me-wmdfz, (accessed August 7, 2021).

67 "Application of IAEA Safeguards in the Middle East," International Atomic Energy Agency, 20 September 1991, https://unidir.org/sites/default/files/2020-10/1991_Resolution\%20 adopted.pdf, (accessed August 7, 2021).

68 "IAEA General Conference agrees not to put the resolution on 'Israeli Nuclear Capabilities and Threat' to a vote," UNIDIR, 1992, https://unidir.org/timeline/1990s/iaea-general-conferenceagrees-not-put-resolution-israeli-nuclear-capabilities-and, (accessed August 7, 2021).
} 
General also decided to suspend further actions in relation to the issue of the Middle East NWFZ, as the Madrid Peace Process seemed to offer a "window of opportunity" for resolving the overall situation. ${ }^{69}$

The Madrid Peace Conference, held from October to November 1991, brought together for the first time all the parties to the conflict in the Middle East. Even though it did not produce tangible results, the participants agreed to stay in dialogue, both on a bilateral and a multilateral track. The multilateral dialogue was aimed, among other things, at finding solutions to key regional problems, arms control, and regional security. ${ }^{70}$ Between 1992 and 1994, the Arms Control and Regional Security Working Group (ACRS) held several meetings where the discussions focused on the feasibility of applying the US-Soviet risk reduction model in the Middle East, such as establishing a hotline, preventing misunderstandings, and avoiding incidents. ${ }^{71}$ However, the deterioration of the peace process, drawing attention to the 1995 NPT Review Conference, and the disagreement between Israel and Egypt regarding the timing of discussions on the nuclear agenda, led to the collapse of the talks. ${ }^{72}$

\section{From the UNGA to the NPT RevCon and back}

With the work of the ACRS Working Group ending in disagreement, Egypt started to put the issue of the Middle East WMDFZ at the forefront

69 "Report of the Secretary General: Establishment of a nuclear-weapon-free zone in the region of the Middle East," UN Secretary General, 1992, A/47/387, September 1992, https://www.unidir.org/sites/default/files/2020-09/1992_0.pdf, (accessed August 7, 2021), 2.

70 "The Madrid Conference 1991," Department of State United States of America, Office of the Historian, https://history.state.gov/milestones/1989-1992/madrid-conference, (accessed August 10, 2021); Mission of Israel to the UN in Geneva, "History: The Peace Process", https://embassies.gov.il/UnGeneva/Aboutlsrael/history/Pages/History-Peace-Process.aspx, (accessed August 10, 2021).

${ }^{71}$ More on US-USSR/RF arms control measures see: Andrej Stefanović, "Deterioration of the global arms control regime and the role of the Vienna Document in reviving stability and confidence in Europe", Journal of Regional Security 16, No. 1, (2021): 56-60.

72 "Parties of the Madrid Peace Conference create the Arms Control and Regional Security (ACRS) working group," UNIDIR, 1991, https://unidir.org/timeline/1990s/1992-1995-armscontrol-and-regional-security-working-group-acrs (accessed August 10, 2021). 
of the NPT. Furthermore, after two decades of inconsequential UNGA resolutions on the Middle East NWFZ, the sentiment among the Arab states was that a formal linkage with the NPT would make a difference, particularly to the way the US, Israel's most important ally, approached the issue. ${ }^{73}$ In 1995, the NPT was about to expire, as the Treaty was originally signed for a duration of 25 years, and at that year's Review Conference (which became known as the Review and Extension Conference) most parties were ready to support an indefinite extension. On the other hand, Egypt and other Arab states signalled their readiness to do so if the three Treaty depositaries (the US, the United Kingdom, and the Russian Federation) sponsor a resolution on the Middle East. The resolution, adopted as part of a package of decisions, called on the Middle Eastern states "to take practical steps... aimed at making progress towards... the establishment of a verifiable Middle East zone free of weapons of mass destruction... and their delivery systems". ${ }^{74}$ Since it was evident that the extension of the Treaty could not have happened without the Arab states' support, the resolution would become part of the NPT review cycle. Despite this, little progress was made on the resolutions' implementation in the subsequent period.

At the 2000 NPT Review Conference, the depositaries did not pay specific attention to the issue. When in 2005, this attitude continued, Egypt, which in 2000 agreed not to prevent the adoption of a consensus document, denied support for the Conference's agenda, which prevented the parties from reaching consensus on the final document. ${ }^{75}$ The failures of the previous two conferences gave rise to reinvigorated efforts to implement the 1995 Resolution. In the 2010 Final Document, the parties emphasised the importance of the full implementation of the resolution and envisaged the three co-sponsors of the resolution and the UN Secretary General, in consultations with the states of the region, convening a conference in 2012 on the establishment of the WMDFZ in the Middle East.

\footnotetext{
${ }^{73}$ Tytti Erästö, The Lack of Disarmament in the Middle East: A Thorn in the Side of the NPT (Stokholm: SIPRI, 2019), 3.

74 "Resolution on the Middle East", 1995 NPT Review Conference, https://unoda-web.s3accelerate.amazonaws.com/wp-content/uploads/assets/WMD/Nuclear/1995-NPT/pdf/ Resolution_MiddleEast.pdf, (accessed August 15, 2021).

${ }^{75}$ Patricia E. Lewis, "A Middle East free of nuclear weapons: possible, probable or pipedream?" International Affairs 89, no. 2 (2013): 438-439.
} 
This Conference was to be attended by all Middle Eastern states and conducted on the basis of the 1995 Resolution. Additionally, the preparations for it would be done by a facilitator, to be appointed by the Secretary General, who would also be mandated to support the implementation of the resolution, assist in conjuring up follow-up steps, and report to the 2015 Review Conference. ${ }^{76}$

Despite the success of the 2010 Review Conference, the US started distancing itself from the outcome due to the fact that Israel's nuclear facilities and the need to place them under IAEA safeguards were mentioned in the Final Document, while there was no word on Iran's noncompliance issues. ${ }^{77}$ In reiterating its support for the establishment of the Zone, which is dependent on the achievement of comprehensive and durable peace, the US announced that it could not allow the holding of a conference that would jeopardise Israel's national security, or that would single out Israel and create unrealistic expectations. ${ }^{78}$ This was precisely the point where the Arab states opted not to submit the resolution on Israeli nuclear capabilities to the IAEA General Conference, as they refrained from aggravating the process further. ${ }^{79}$

In October 2011, it was announced that the implementation of the 2010 decision had commenced being implemented through the appointment of a Finnish diplomat, Ambassador Jaakko Laajava, as the facilitator of the process, while Finland was designated as the host country for the 2012 Conference. ${ }^{80}$ However, as the end of 2012 was drawing to a

76 "2010 NPT Review Conference Final Document," https://www.nonproliferation.org/wpcontent/uploads/2015/04/2010_fd_part_i.pdf, (accessed August 16, 2021): 29-30.

77 Lewis, "A Middle East free of nuclear weapons: possible, probable or pipe-dream?," 439.

78 "Statement by the National Security Advisor, General James L. Jones, on the NonProliferation Treaty Review Conference," The White House Office of the Press Secretary, https://obamawhitehouse.archives.gov/realitycheck/the-press-office/statement-nationalsecurity-advisor-general-james-l-jones-non-proliferation-treaty- (accessed August 16, 2021).

79 "Arab Group refrains from putting the draft resolution on 'Israeli nuclear capabilities' to a vote at the IAEA General Conference," UNIDIR, 2011, https://unidir.org/timeline/2010s/ arab-group-refrains-putting-draft-resolution-israeli-nuclear-capabilities-vote-iaea (accessed August 16, 2021).

80 "Finland appointed as Host Government, Facilitator for 2012 Conference on Middle East as Zone Free of Nuclear, All Mass-Destruction Weapons," United Nations, 2011, https://www.un.org/press/en/2011/sg2180.doc.htm, (accessed August 16, 2021). 
close, the US announced unilaterally that the conference could not be held due to ongoing unfavourable conditions in the Middle East and that the states concerned had not reached an agreement on the terms of reference of the Conference. ${ }^{81}$ Russia affirmed that such a decision could only be taken following the explicit consent of the countries concerned. Also, in the case of postponement, they argued that new dates ought to be set right away. ${ }^{82}$ In addition, the League of Arab States characterised the postponement as a violation of obligations that stemmed from the NPT and requested the facilitator to work out new dates. However, no alternative was agreed. ${ }^{83}$ The failure to convene the Conference signalled the limitations of furthering the WMDFZ initiative within the NPT as well as the extent to which great powers could exert their influence on the process. Disagreement over the convening of the Conference was the reason for the failure to adopt the 2015 NPR RevCon Final Document.

During the 2000s, the renewed point of concern was also the supposed Iranian nuclear weapons programme, and, after several failures, the Joint Comprehensive Plan of Action (JCPOA) was finally signed in 2015. However, whatever aspiration existed for using the JCPOA as a trigger mechanism for advancing the WMDFZ in the Middle East soon went away, as in May 2018, President Trump announced the US's departure from the Agreement, which put into question its future existence. To this day, the new Biden administration did not return to this agreement regardless of numerous pressures and mediation from the EU in the first half of 2021 and prominent US-based arms control associations. ${ }^{84}$

81 "2012 ME WMDFZ conference is postponed", UNIDIR, 2012, https://unidir.org/timeline/ 2010/2012-me-wmdfz-conference-postponed?timeline=12, (accessed August 16, 2021).

82 "Press Statement on the 2012 Conference on the Establishment of a Middle East Zone Free of Weapons of Mass Destruction," Ministry of Foreign Affairs of the Russian Federation, https://unidir.org/sites/default/files/2020-07/2012-11-24_Russian\%20Statement\%20on\%20postponement\%20of\%20the\%202012\%20conference.pdf, (accessed August 16, 2021).

83 "League of Arab States criticizes decision to postpone the 2012 ME WMDFZ conference," UNIDIR, 2013, https://unidir.org/timeline/2010/league-arab-states-criticizes-decisionpostpone-2012-me-wmdfz-conference?timeline=13, (accessed August 16, 2021).

${ }^{84}$ On the position of the EU toward the WMD see: Marina T. Kostić, "European Union and the Weapons of Mass Destruction: Policy, Threat, Response", Romanian Review of Political Sciences and International Relations XVIII, No. 2 (2021):135-155. 
Finally, at the second session of the Preparatory Committee for the Tenth NPT Review Conference in 2018, the US effectively divorced the issue of the Middle East WMDFZ from the NPT, stating that the Treaty's review cycle could not be the primary mechanism for advancing the zone's establishment. It was also reiterated that the establishment of the zone could not be isolated from the overall regional political and security situation in the region. Ultimately, the US concluded that the regional states should take the necessary practical steps in order to ensure the political, diplomatic, and security conditions required for the WMDFZ to be instituted. ${ }^{85}$ However, taken away by the failures in 2015 and not expecting that the process within the NPT could get back on track, the League of Arab States, in March 2018, was prepared for such a scenario. In an Action Plan adopted during this period, it envisaged the implementation of the 1995 ME Resolution through mobilising efforts at the $73^{\text {rd }}$ session of the UNGA, as a way of deferring the issue of the Middle East WMDFZ back to the UNGA. ${ }^{86}$ These efforts paid dividends as the Arab states succeeded in passing the decision on convening a conference on the establishment of a Middle East zone free of nuclear weapons and other WMD through the UNGA in December 2018. The decision was adopted with the votes of 103 countries, while 6 voted against it, among which were the US and Israel. ${ }^{87}$ The decision mandated the Secretary General to convene a conference no later than 2019 and to invite all regional states, the three co-sponsors of the 1995 Resolutions, and the other NWS. The conference's mandate was a step further compared to the 2010 agreement, as it provided for the Conference to elaborate on a legally-binding treaty on the establishment

85 "Preparatory Committee for the 2020 Review Conference of the Parties to the Treaty on the Non-Proliferation of Nuclear Weapons, Working Paper submitted by the USA on Establishing Regional Conditions Conducive to a Middle East Free of Weapons of Mass Destruction and Delivery Systems," https://www.state.gov/wp-content/uploads/2020/ 01/2018-04-19-US-Working-Paper-33-MEWMDFZ.pdf, (accessed August 16, 2021).

86 "Resolution 8251," League of Arab States, March 7, 2018, https://unidir.org/sites/default /files/2020-07/2018-03-07_EN_LAS\%20Ministerial\%20Council\%20adopts\%20SOC\% 20action\%20plan\%20for\%20the\%20implementation\%20of\%201995\%20Resolution\%20on \%20the\%20Middle\%20East.pdf, (accessed August 16, 2021).

87 "Report of the First Committee," UN General Assembly, Seventy-third session, November 19, 2018, https://undocs.org/A/73/513, (accessed August 15, 2021). 
of a WMD free zone in the Middle East. In performing this task, it was envisaged for the conference to be convened at annual sessions until this task was completed. ${ }^{88}$ Nonetheless, the adoption of this decision was not without consequences on other fronts. Specifically, the consensual adoption of the UNGA resolution on the Middle East NWFZ was put to an end at this very session, as the Israeli delegation referred to the "imposition of the new unilateral and destructive" decision and warned that the Arab states had shifted the status quo, which made it impossible for Israel to continue supporting the resolution as well as cooperating with other regional arms control initiatives. ${ }^{89}$ This remark was seconded by the US delegation, which blamed the Arab states for advancing a short-sighted approach of coercive measures designed to isolate cooperative principles at the cost of consensus-based solutions. ${ }^{90}$ The UK delegation decided to abstain from voting, as for them it became clear that the resolution no longer had support among the countries in the region. ${ }^{91}$ On the other hand, the Russian Federation accused the US and the UK of sabotaging the adoption of the consensus document at the 2015 NPT Review Conference, despite bearing a major part of the responsibility for implementing the 1995 Resolution. The Russian delegation pointed to the fact that without any dialogue, there could be no progress and no agreement on this issue. ${ }^{92}$ Despite these cracks and the abandoning of consensus, the resolution succeeded in being adopted by the votes of 171 member states and only two votes against (the US and Israel). ${ }^{93}$

Consistent with the 2018 decision, the first session of the Conference on the Establishment of a Middle East Zone Free of Nuclear Weapons and

88 "Convening a conference on the establishment of a Middle East zone free of nuclear weapons and other weapons of mass destruction," UN General Assembly, Decision 73/546, A/73/513, December 22, 2018, https://undocs.org/A/73/513, (accessed August 15, 2021).

89 "Official Records," UN General Assembly, Seventy-third session, First Committee, 27th meeting, November 2, 2018, https://undocs.org/A/C.1/73/PV.27, (accessed August 17, 2021).

90 "Official Records," UN General Assembly, Seventy-third session, First Committee, 26th meeting, November 1, 2018, https://undocs.org/A/C.1/73/PV.26, (accessed August 15, 2021).

${ }^{91}$ Ibid.

92 "Official Records," First Committee, 27th meeting.

93 Ibid. 
other WMD was held in New York on November 18-22, 2019, with the representatives of all participating states in attendance, apart from Israel and the US. The Conference adopted a Political Declaration, in which the aim of elaborating a legally binding treaty to establish a Middle East WMDFZ was ascertained. This was to be done on the basis of arrangements freely arrived at by the regional states following the rule of consensus. The realisation of such a goal would be facilitated by the participation of all states in the region in an open and inclusive manner. Even though an agreement was made that annual sessions of the Conference ought to be held in November of each year, the 2020 session was postponed to a later date, due to the ongoing COVID-19 pandemic. ${ }^{94}$

\section{CONCLUSION: ASSESSING THE CONDITIONS FOR THE MIDDLE EAST NWFZ/WMDFZ AND THE WAY AHEAD}

Insistence and new orientation towards creating a zone free of all WMD in the Middle East surely complicated the equation, since no such zone still exists, and it looks like it serves as some kind of experiment for both practitioners and scholars to try to develop and implement such a concept. This poses an additional layer of uncertainty in the process since it requires the regional states to comply with an additional set of international disarmament norms, not just the NPT and the IAEA safeguards. But, as we could see from the analysis of already established NWFZs, ratification or accession to the NPT did not always precede the forming or entering the Zone, which was the case of the Latin American NWFZ. Thus, Israel's primary participation in the NPT, before joining the proposed Zone, would be highly expected, but it would not be without exception if it becomes part of the Zone without prior accession to the NPT. In any case, it is selfevident that Israel would have to abandon its nuclear weapons or prove through some other agreed mechanism that it does not possess such weapons in order to become part of the Zone. Also, other states would be expected to enter into other agreements that regulate other types of WMD.

94 "Conference on the Establishment of a Middle East Zone Free of Nuclear Weapons and Other Weapons of Mass Destruction", United Nations, 2020, Accessed 27 August 2021, https://www.un.org/disarmament/topics/conference-on-a-mezf-of-nwandowomd/. 
In this context, attempts to create a WMDFZ additionally complicate the possibilities of verification of the regime since, for example, the BTWC does not have verification mechanisms and the possibility of some kind of negative security assurance from NWSs.

As we mentioned in the theoretical part of the paper, some elements critical for the establishment of NWFZs might be of importance for the MEWMDFZ. First, for now, it seems that all countries from the region use the idea of the NWFZ/WMDFZ as an instrument for attaining tactical policy goals, and not all of them seem to see this Zone as a tool for enhancing their security. Setting differences and ending war is precisely a point of divergence, as there are diametrically opposed positions relating to the relationship between achieving peace in the region and establishing the Zone; while Israel claims that peace should be achieved first in order to pave the way for other goals, Arab states argue that these two processes should be dealt with concurrently, as they are mutually reinforcing. Secondly, the NWFZs comprise states in the same category of power. They are usually developing states, with most of them having equal power without the possibility of establishing regional hegemony. However, in the Middle East, there is a clear asymmetry in power and threat perception (strong US, extension of threat perception of other states to the US, as well as alleged Israel's nuclear capabilities). It is clear that this runs contrary to the efforts to establish the MEWMDFZ. Third, none of the countries participating in any of the existing NWFZs had their existence and recognition denied as much as in the case with Israel. This also clashes with the establishment of the Zone. Fourth, the Middle East countries do not border any of the NWS and are not essential for the preservation of strategic stability among superpowers. Instead, they are areas of contested superpowers' interests, and their influence in the region is greater than expected. These are reasons that are also detrimental to the establishment of the Zone. Fifth, it will hardly be possible for Israel to relinquish its nuclear weapons just in order to enter the Zone. State parties had various reasons for abandoning their nuclear weapons programs, such as in the case of South Africa, but none of them was for the reason of entering the NWFZ.

Having in mind these variables, it seems like the regional states' individual commitments not to develop nuclear weapons, or other weapons of mass destruction, would be a more feasible option. Thus, the 
creation of the Zone is highly improbable, but it still remains high on the agendas of all involved states, including great powers. One of the explanations for this can be found in the context of the pursuance of the non-proliferation agenda of great powers, as well as some organizations, such as the EU. They need to maintain the credibility of these agendas and, through the involvement of all states in the region, continue to work on the elimination of the possibility that some of the "unfriendly" states could come into the possession of nuclear weapons. However, the credibility of this approach does not stop at the regional level and non-proliferation efforts, since for the Arab states, this project also has a wider dimension in the context of pressuring great powers to do more on disarmament. Actually, the framing of the WMD Free Zone as part of non-proliferation instead of a larger disarmament agenda weakens the support of Arab states for the creation of the Zone. On the other hand, without a credible nonproliferation agenda and arms control in the region, Israel might continue to view the MEWMDFZ as a means of other states' attempts to disarm it.

In the end, the goal of establishing the Middle East WMDFZ appears to be a "moving target", with the interests and preferences of the key players continuously susceptible to alteration, which makes the process that much difficult, and at times even impossible to achieve. Nonetheless, it is clear that efforts to establish the zone will continue, as the process has become too important to the security interests of regional states and great powers, which have already invested too much in the process over the last nearly five decades.

\section{BIBLIOGRAPHY}

1995 NPT Review Conference. "Resolution on the Middle East". https:// unoda-web.s3-accelerate.amazonaws.com/wp-content/uploads/ assets/WMD/Nuclear/1995-NPT/pdf/Resolution_MiddleEast.pdf

2010 NPT Review Conference Final Document. https://www.non proliferation.org/wp-content/uploads/2015/04/2010_fd_part_i.pdf

2012 ME WMDFZ conference is postponed". United Nations Institute for Disarmament Research. Accessed 27 August 2021. https://unidir.org/ timeline/2010/2012-me-wmdfz-conference-postponed?timeline=12 
Alvarez, Valeria Puga, "Functional peace? The "first wave" of NuclearWeapon-Free Zonesproposals in the Cold War", Grotius, https:// www.academia.edu/43482987/Functional_peace_The_first_wave_of_ nuclear_weapon_free_zones_proposals_in_the_Cold_War?email_wor k_card=thumbnail, (accessed August 20, 2021).

"Arab Group refrains from putting the draft resolution on "Israeli nuclear capabilities" to a vote at the IAEA General Conference". United Nations Institute for Disarmament Research. https://unidir.org/timeline/2010s/ arab-group-refrains-putting-draft-resolution-israeli-nuclear-capabilitiesvote-iaea

BMEIA Federal Ministry Republic of Austria European and International Affairs. "Nuclear-Weapon-Free Zone. Accessed 27 August 2021. https:// www.bmeia.gv.at/en/european-foreign-policy/disarmament/weaponsof-mass-destruction/nuclear-weapons/nuclear-weapon-free-zones/

Campbell, John C. 1972. "The Soviet Union and the United States in the Middle East". The Annals of the American Academy of Political and Social Science 401: 126-135.

Department of State United States of America, Office of the Historian. "The Madrid Conference 1991". Accessed 27 August 2021. https://history. state.gov/milestones/1989-1992/madrid-conference

Disarmament Commission, 1956. Official Records, Supplement for January to December 1956. https://s3.amazonaws.com/unoda-web/documents /library/Supplement\%20for\%201956.pdf

Dowty, Alan. 1978. "Nuclear Proliferation: The Israeli Case". International Studies Quarterly 22 (1): 79-120.

"Egyptian delegation walks out of 2013 NPT PrepCom in protest over the lack of progress on the ME WMDFZ". United Nations Institute for Disarmament Research. Accessed 27 August 2021. https://unidir.org/ timeline/2010s/egyptian-delegation-walks-out-2013-npt-prepcomprotest-over-lack-progress-me-wmdfz

Erästö, Tytti. 2019. The Lack of Disarmament in the Middle East: A Thorn in the Side of the NPT. Stokholm: SIPRI.

General Assembly. Decision 73/546, Convening a conference on the establishment of a Middle East zone free of nuclear weapons and other 
weapons of mass destruction. A/73/513. 22 December 2018. https:// undocs.org/A/73/513

Goldblat, Jozef. 2002. Arms Control: The New Guide to Negotiations and Agreements. London, Thousand Oaks and New Delhi: PRIO, SIPRI and SAGE Publications.

Goldschmidt, Pierre. 2016. "A Realistic Approach toward a Middle East Free of WMD", July 6. https://carnegieendowment.org/2016/07/07/realisticapproach-toward-middle-east-free-of-wmd-pub-64039

Hamel-Green, Michael. 2011. "Peeling the orange: regional paths to a nuclear-weapon-free world". In: Nuclear-weapon-free zones, edited by Kerstin Vignard and Ross McRae, 3-14. Geneva: United Nations for Disarmament Research.

Hellestveit, Cecilie, and Mekonnen, Daniel. 2014. "Nuclear weapon-free zones: the political context". In: Nuclear Weapons Under International Law, edited by GyoNyustuen, Stuart Casey-Maslen and Annie Golden Bersagel, 347-373.Camrbidge: Cambridge University Press.

"IAEA General Conference agrees not to put the resolution on "Israeli Nuclear Capabilities and Threat" to a vote". United Nations Institute for Disarmament Research. Accessed 27 August 2021. https://unidir.org/ timeline/1990s/iaea-general-conference-agrees-not-put-resolutionisraeli-nuclear-capabilities-and

"IAEA resolution on the "Israeli nuclear capabilities and threat" is adopted for the first time". United Nations Institute for Disarmament Research. Accessed 27 August 2021. https://unidir.org/timeline/1980s/iaearesolution-israeli-nuclear-capabilities-and-threat-adopted-first-time

International Atomic Energy Agency. 1991. Application of IAEA Safeguards in the Middle East. 20 September 1991. https://unidir.org/sites /default/files/2020-10/1991_Resolution\%20adopted.pdf

Iran and Egypt co-sponsor a resolution calling for the establishment of a nuclear-weapon-free zone in the Middle East. Accessed 27 August 2021. https://unidir.org/timeline/1970s/iran-and-egypt-co-sponsorresolution-calling-establishment-nuclear-weapon-free-zone

Joint Comprehensive Plan of Action. Vienna, 14 July 2015, https://www.europarl.europa.eu/cmsdata/122460/full-text-of-the-irannuclear-deal.pdf. 
Kostić, Marina T., "Controversial issues regarding the extension of the "New START" Treaty: Can the USA and Russia preserve existing strategic arms control?", Serbian Political Thought 70, No. 4, (2020): 123-149.

Kostić, Marina T., "European Union and the Weapons of Mass Destruction: Policy, Threat, Response", Romanian Review of Political Sciences and International Relations XVIII, No. 2 (2021):135-155.

"League of Arab States criticizes decision to postpone the 2012 ME WMDFZ conference": United Nations Institute for Disarmament Research. Accessed 27 August 2021. https://unidir.org/timeline/2010/league-arab -states-criticizes-decision-postpone-2012-me-wmdfz-conference? timeline $=13$

League of Arab States. Resolution 8251. 7 March 2018. https://unidir.org/ sites/default/files/2020-07/2018-03-07_EN_LAS\%20Ministerial\% 20Council\%20adopts\%20SOC\%20action\%20plan\%20for\%20the\%20im plementation\%20of\%201995\%20Resolution\%20on\%20the\%20Middle \%20East.pdf

Lewis, Patricia E. 2013. "A Middle East free of nuclear weapons: possible, probable or pipe-dream?". International Affairs 89 (2): 433-450.

Marusza, Zoltan. 2010. Denuclearization in Central Europe? The Rapacki Plan during the Cold War. Cold War History Research Center. Budapest.

Ministry of Foreign Affairs of the Russian Federation. "Press Statement on the 2012 Conference on the Establishment of a Middle East Zone Free of Weapons of Mass Destruction". Accessed 27 August 2021. https:// unidir.org/sites/default/files/2020-07/2012-11-24_Russian\%20 Statement \%20on\%20postponement\%20of\%20the\%202012\%20conference.pdf

Mission of Israel to the UN in Geneva. "History: The Peace Process". Accessed 27 August 2021. https://embassies.gov.il/UnGeneva/About Israel/history/Pages/History-Peace-Process.aspx

Müller, Harald et al., "From Nuclear Weapons to WMD: The Development and Added Value of the WMD-Free Zone Concept", Non-Proliferation Papers, No. 31, September 2013, EU Non-Proliferation Consortium, https://www.sipri.org/sites/default/files/EUNPC_no-31.pdf, (accessed July 30, 2021).

Nations Unies Assemblee. Lettre datéee du 23 octobre 1980, adressée au Secrétaire général par le Représentant permanent d'Israel auprès de 
I'Organisation des Nations Unies. A/C.1/35/8. 24 Octobre 1980. https://digitallibrary.un.org/record/16331?!n=en

Nuclear Threat Initiative. "Weapons of Mass Destruction in the Middle East". Accessed 27 August 2021. https://www.nti.org/analysis/articles/ weapons-mass-destruction-middle-east/

"Nuclear-Weapon-Free Zones", UNODA, https://www.un.org/disarmament /wmd/nuclear/nwfz/, (accessed August 15, 2021).

Ozinga, James R. 1964. An Analysis of the Rapacki Plan to Denuclearize Central Europe. Master's Theses. Graduate College. Western Michigan University

"P5 express their support for a ME WMDFZ". United Nations Institute for Disarmament Research, Accessed 27 August 2021. https://unidir.org/ timeline/1990s/p5-express-their-support-me-wmdfz

"Parties of the Madrid Peace Conference create the Arms Control and Regional Security (ACRS) working group". United Nations Institute for Disarmament Research. Accessed 27 August 2021. https://unidir. org/timeline/1990s/1992-1995-arms-control-and-regional-securityworking-group-acrs

Platias, Athanassios G. and R. J. Rydell, "International Security Regimes: the Case of a Balkan Nuclear-Free Zone", in: South-Eastern Europe after Tito, a Powder-Keg for the 1980s, ed. David Carlton and Carlo Schaerf (London: Macmillan Press, 1983), 105-130.

Preparatory Committee for the 2020 Review Conference of the Parties to the Treaty on the Non-Proliferation of Nuclear Weapons. Working Paper submitted by the USA on Establishing Regional Conditions Conducive to a Middle East Free of Weapons of Mass Destruction and Delivery Systems. https://www.state.gov/wp-content/uploads/2020/01/201804-19-US-Working-Paper-33-MEWMDFZ.pdf

"Protocols to the Nuclear-Weapon-Free-Zone Treaties", https://www.un.

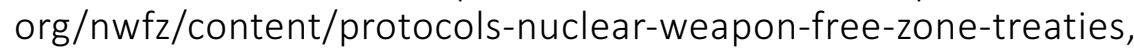
(accessed August 15, 2021).

"Soviet Initiative calls for a nuclear-weapon-free zone in the Middle East". United Nations Institute for Disarmament Research. Accessed 27 August 2021. https://unidir.org/timeline/1950s/soviet-initiative-callsnuclear-weapon-free-zone-middle-east 
Stefanović, Andrej, "Deterioration of the global arms control regime and the role of the Vienna Document in reviving stability and confidence in Europe", Journal of Regional Security 16, No. 1, (2021): 56-60.

The Rapacki Plan, 14 February 1958. https://www.cvce.eu/en/obj/the_ rapacki_plan_warsaw_14_february_1958-en-c7c21f77-83c4-4ffc-8cca30255b300cb2.html

The White House Office of the Press Secretary. "Statement by the National Security Advisor, General James L. Jones, on the Non-Proliferation Treaty Review Conference". Accessed 27 August 2021. https://obamawhite house.archives.gov/realitycheck/the-press-office/statement-nationalsecurity-advisor-general-james-l-jones-non-proliferation-treaty-

The White House: The Office of the Press Secretary. The Fact Sheet: Middle East Arms Control Initiative. May 29 1991. https://www.dscu.mil/ Pubs/Indexes/Vol\%2013_4/Fact\%20Sheet\%20Middle\%20East\%20Arm s\%20Control\%20Initiative.pdf

Treaty on the Non-Proliferation of Nuclear Weapons. 1 July 1968. https://treaties.unoda.org/t/npt

UN General Assembly. Final Document of the Tenth Special Session of the General Assembly. 1978. https://digitallibrary.un.org/record/218448 ? ln=en

UN General Assembly. Request for the inclusion of an item in the provisional agenda of the twenty-ninth session. A/9693/Add. 3. 17 September 1974. https://unidir.org/sites/default/files/2020-11/1974\%20Shah\% 20UN\%2Oletter.pdf

UN General Assembly. Request for the inclusion of an item in the provisional agenda of the twenty-ninth session: establishment of a nuclear-free zone in the region of the Middle East. A/9693. July 1974. https://unidir. org/sites/default/files/2020-11/1974\%20Iran\%20request.pdf

UN General Assembly. Resolution 2028, Non-proliferation of nuclear weapons, A/RES/2028. 19 November 1965, https://www.security councilreport.org/atf/cf/\%7B65BFCF9B-6D27-4E9C-8CD3-CF6E4FF96 FF9\%7D/Disarm\%20ARES2028.pdf.

UN General Assembly. Resolution 3263, Establishment of a nuclearweapon-free zone in the region of the Middle East, A/RES/3263. 9 
December 1974. https://www.securitycouncilreport.org/un-documents /document/disarm-ares3263-xxix.php

UN General Assembly. Resolution 34/89, Israeli nuclear armament, A/RES/34/89. 11 December, 1979. https://undocs.org/en/A/RES/34/89

UN General Assembly. Resolution 3472, Comprehensive Study of the question of nuclear-weapon-free zones in all its aspects, 11 December 1975, https://digitallibrary.un.org/record/640307?ln=en

UN General Assembly. Resolution 35/147, Establishment of a nuclearweapon-free zone in the region of the Middle East. A/35/PV.94. 12 December 1980. https://undocs.org/en/A/RES/35/147

UN General Assembly. Resolution 45/52, Establishment of a nuclearweapon-free zone in the region of the Middle East, A/RES/45/52. 19 December, 1990. https://digitallibrary.un.org/record/104358?!n=en

UN General Assembly. Seventy-third session. First Committee. $26^{\text {th }}$ meeting. Official Records. 1 November 2018. https://undocs.org/A/C.1/73/PV.26

UN General Assembly. Seventy-third session. First Committee. $27^{\text {th }}$ meeting. Official Records. 2 November 2018. https://undocs.org/A/C.1/73/PV.27

UN General Assembly. Seventy-third session. Report of the First Committee. 19 November 2018. https://undocs.org/A/73/513

UN General Assembly. Thirty-fourth session Official Records. $70^{\text {th }}$ Plenary meeting. 16 October 1979. https://digitallibrary.un.org/record/754 036 ? $\ln =e n$

UN General Assembly. Twenty-fifth session Official Records. $1857^{\text {th }}$ plenary meeting. 1 October 1970. https://digitallibrary.un.org/record/740456 ? In=en

UN General Assembly. Twenty-sixth session Official Records. 1941 ${ }^{\text {st }}$ plenary meeting. 27 September 1971.digitallibrary.un.org/record/734 914? In=en

UN Secretary General. 1975. Report of the Secretary General on the establishment of a nuclear-weapon-free zone in the region of the Middle East. S/11778. https://www.unidir.org/sites/default/files/202010/1975_SecGenReport.pdf

UN Secretary General. 1980. Comprehensive study on nuclear weapons. Report of the Secretary General. A/35/392. 12 September 1980. https://digitallibrary.un.org/record/15382? ln=en 
UN Secretary General. 1992. Report of the Secretary General: Establishment of a nuclear-weapon-free zone in the region of the Middle East. A/47/387. September 1992. https://www.unidir.org/sites/ default/files/2020-09/1992_0.pdf

UN Security Council. Resolution 487 (1981), On the Israeli military attack Iraqi nuclear facilities, S/RES/487, 19 June 1981. https://digitallibrary.un. org/record/22225? In=en

UN Security Council. Resolution 687 (1991), On restoration of the sovereignty, independence and territorial integrity of Kuwait, S/RES/ 687. 3 April 1991. https://digitallibrary.un.org/record/110709? In=en

United Nations. 2011. "Finland appointed as Host Government, Facilitator for 2012 Conference on Middle East as Zone Free of Nuclear, All MassDestruction Weapons". Accessed 27 August 2021. https://www.un.org/ press/en/2011/sg2180.doc.htm

United Nations. 2020. "Conference on the Establishment of a Middle East Zone Free of Nuclear Weapons and Other Weapons of Mass Destruction". Accessed 27 August 2021. https://www.un.org/ disarmament/topics/conference-on-a-mezf-of-nwandowomd/

University of Virginia Miller Center. 1991. Address Before a Joint Session of Congress on the End of the Gulf War. March 6 1991. Accessed 27 August 2021. https://millercenter.org/the-presidency/presidentialspeeches/march-6-1991-address-joint-session-congress-end-gulf-war

Vesa, Unto. 1975. "The Revival of Proposals for Nuclear-Free Zones". Instant Research on Peace and Violence 5 (1): 42-51.

Vienna Center for Disarmament and Non-Proliferation. "From the Iran Nuclear Deal to a Middle East Zone?". Accessed 27 August 2021. https://vcdnp.org/from-the-iran-nuclear-deal-to-a-middle-east-zone/

Vukadinović, Radovan, "Prospects for Mediterranean Security: a Yugoslav View," in: South-Eastern Europe after Tito, a Powder-Keg for the 1980s, ed. David Carlton and Carlo Schaerf (London: Macmillan Press, 1983), 152-160.

Zak, Chen and Sabet, Farzan. 2021. From the Iran Nuclear Deal to a Middle East Zone? Lessons from the JCPOA for an ME WMDFZ. Geneva: UNIDIR. 